\title{
PROFIT SHARING \\ DALAM PENGELOLAAN RUMAH MAKAN “PADANG”
}

\author{
Fauzi Solihin ${ }^{1}$
}

\begin{abstract}
Article discusses profit sharing in running a "Padang" restaurant. Profit sharing always increase sense of belonging every employee and support the management function. It can be concluded that profit sharing can motivated employee to increase working performance and increase sense of belonging and responsibility. It also can increase continuous improvement team work between employee.
\end{abstract}

Keywords: profit sharing, restaurant

ABSTRAK
Artikel membahas bagi hasil dalam mengelola rumah makan, dalam hal ini rumah makan
"Padang”. Usaha bagi hasil (profit sharing) meningkatkan rasa kepemilikan (sense of belonging)
setiap karyawan dan mendukung kelancaran pelaksanaan fungsi manajemen. Dapat disimpulkan
bahwa usaha bagi hasil sangat memotivasi karyawan untuk meningkatkan kinerjanya dan
menumbuhkan rasa kepemilikan usaha dan tanggung jawab serta peningkatan kerja sama
berkesinambungan antarsesama karyawan.
Kata kunci: bagi hasil, rumah makan

\footnotetext{
${ }^{1}$ Staf Pengajar STIE Swadaya \& Fakultas Ekonomi, UBiNus, Jakarta
} 


\section{PENDAHULUAN}

Pola bagi hasil bukanlah suatu hal yang baru di Indonesia karena dari beberapa generasi terdahulu sudah dikenal istilah bagi hasil, terutama bagi para petani yang tidak mempunyai tanah untuk digarap. Mereka mengerjakan tanah milik orang lain sehingga mereka disebut petani “penggarap”. Hasil usaha yang diperoleh dibagi sedemikian rupa antara pemilik lahan dengan petani penggarap sesuai perjanjian yang telah ditetapkan sebelumnya

Dalam pengelolaan rumah makan, pada prinsipnya juga dikenal dua pihak yang terkait, yaitu Pemilik Modal (pemodal) dan Pengelola Usaha. Tidak ada catatan yang menyebutkan siapa peletak dasar sistem bagi hasil pada usaha jasa rumah makan itu karena pengusaha rumah makan saat ini berpegang pada kata "kelaziman berlaku". Lazimnya bagi hasil antara pemodal dan pengelola usaha, 50:50 diistilahkan "Diparo" , dapat diartikan dibagi dua. Malah saat ini, sudah ada yang melakukan bagi hasil dengan ratio 45:55 atau 40:60. Hal itu merupakan langkah/sikap memberi penghargaan lebih kepada para pekerja sehingga mereka terpacu untuk mengembangkan usaha dengan lebih baik lagi.

Sering dikatakan bahwa terkenal atau tidak terkenalnya suatu rumah makan/restoran terkait dengan kualifikasi atau keahlian "Koki” atau "Juru Masak” yang mengatur racikan bumbu masakan dan menu makanan dan minuman. Karena Koki atau Juru Masak yang menjadi kunci penentu pada ketenaran suatu rumah makan/restoran, sering pula si “Koki” alias "Juru Masak” itu yang menjadi pimpinan (leader) dalam pengelolaan operasional rumah makan "Padang”. Hal itu terlihat dalam pembagian hasil usaha, yaitu koki mendapat porsi yang lebih besar dari peserta yang lainnya

\section{PEMBAHASAN}

\section{Organisasi Pelayanan}

Secara garis besar, terdapat tiga unit kerja dalam operasional rumah makan "Padang”.

1. Juru Masak

Tugas utama Juru Masak adalah meramu masakan sehingga mendapatkan citarasa yang baik, spesifik, dan disenangi oleh para konsumen. Agar kualitas masakan/makanan sesuai standar rasa/selera si Juru masak, pengadaan bahan baku masakan berada di bawah pengawasan Juru masak. Untuk tugas tersebut maka Juru masak didampingi dua kelompok asisten masing masing sebagai berikut.

a. Koki I, dengan tugas meracik ramuan/bumbu masak dan memasak

b. Koki II, dengan tugas belanja bahan, membersihkan bahan, dan peralatan

2. Keuangan

Bagian Keuangan lazimnya dipimpin seorang Kasir Kepala dan didampingi oleh satu atau beberapa orang Kasir Kasir Kepala, disamping mengawasi penerimaan pembayaran yang 
diterima kasir dari konsumen, juga melakukan pembayaran sesuai permintaan belanja bahan dari Juru Masak dan pembayaran kepada pihak ketiga serta melakukan perhitungan hasil usaha dan bagi hasil untuk setiap karyawan.

3. Pelayanan

Unit Pelayanan (dalam istilah Minang disebut "Palung") adalah mereka yang menerima pesanan makanan dan minuman dari konsumen yang datang, manata makanan dan minunan di meja, menyiapkan peralatan makan, membersihkan meja makan, dan ruangan. Pada unit itu, terdapat dua kelompok petugas sebagai berikut.

a. Kelompok pertama menyiapkan pesanan dan menata makanan dan minuman di meja tamu serta menyiapkan peralatan makan lainnya. Kelompok itu sering terlihat unjuk keterampilan dengan membawa 8 sampai dengan 10 piring makanan pada kedua tangannya. Hal itu merupakan ciri khas rumah makan yang populer

b. Kelompok kedua adalah yang bertugas membersihkan meja dari sisa makanan, merapikan meja dan kursi, membersihkan ruangan, lantai, serta peralatan makan dan minum.

\section{Cara Pembagian Bagi Hasil}

Baik di daerah asalnya di Minang (Sumatera Barat) maupun di perantauan (di daerah lain), bagi hasil yang dilakukan tidak menggunakan prosentase (\%) tetapi menggunakan istilah "Mato" atau Mata yang dapat diartikan dengan "Point" atau ratio. Sesuai struktur unit atau kelompok yang terkait dalam operasional pelayanan Rumah Makan "Padang” sebagaimana disebutkan sebelumnya maka komposisi bagi hasil kelompok operasional sebagai berikut.

$\begin{array}{ll}\text { Koki Kepala } & : \text { 6,0-7,0 mata/point } \\ \text { Koki I } & : 4,0-5,0 \text { mata/point } \\ \text { Koki II } & : 2,0-3,5 \text { mata/point } \\ & \\ \text { Kasir Kepala } & : 5,0-5,5 \text { mata/point } \\ \text { Kasir } & : 3,0-4,0 \text { mata/point } \\ & \\ \text { Palung } & : 4,0-4,5 \text { mata / point } \\ \text { Pelayan } & : 3,0-3,5 \text { mata / point } \\ \text { Cuci piring } & : \text { 2,0 }-2,5 \text { mata / point }\end{array}$

Penetapan skala pada lajur kiri merupakan komposisi pada awal bekerja sedangkan pada lajur kanan merupakan komposisi atas kenaikan point setelah beberalama bekerja/cukup pengalaman kerja dan memperhatikan dedikasi, loyalitas, serta keterampilan pegawai yang bersangkutan.

Nominal keuntungan yang dibagi adalah hasil bersih usaha, yaitu setelah diperhitungkan biaya produksi (cost of goods sold), penggantian peralatan yang rusak/penghapusan peralatan, pajak, dan zakat hasil usaha. Perhitungan zakat itu merupakan penerapan syariah Islam dan atas pendapatan seseorang dibebankan zakat sebesar 2,5\% yang menjadi hak para fakir miskin dan kelompok lain yang telah ditetapkan dalam ajaran Islam. 
Contohnya sebagai berikut.

1. Hasil bersih usaha setelah dkurangi zakat 200 juta.

2. Jumlah mata/point seluruh karyawan: 50 mata/point

Pembagian hasil usaha sebagai berikut.

1. Pemodal: $50 \%=$ Rp100 juta

2. Kelompok operational : $50 \%=\mathrm{Rp} 100$ juta

3. $\quad$ Koki Kepala: 6/50 x Rp100 juta $=$ Rp12 juta

4. Kasir Kepala: $5 / 50 \times$ Rp100 juta $=$ Rp10 juta

5. Cuci Piring: $2 / 50 \times$ Rp100 juta = Rp4 juta

6. dan seterusnya.

Bila dibandingkan dengan sistem gaji tetap maka sistem bagi hasil memiliki beberapa keunggulan, antara lain sebagai berikut.

1. Pembagian bagi hasil dilakukan secara terbuka.

2. Pengalaman/masa kerja atau keterampilan tetap mendapat penghargaan.

3. Menumbuhkan motivasi dan kerja sama yang erat karena kenaikan hasil usaha akan dinikmati bersama secara proportional sesuai bidang tugasnya.

4. Terjadi perbaikan kualitas pelayanan terutama aspek manusia (motivasi) secara terus menerus (continues improvement).

5. Karyawan akan mengembangkan diri secara terus menerus sehingga mampu bekerja dengan keterampilan terbaik melalui pendidikan dan latihan.

6. Karyawan akan melibatkan diri melalui sistem saran dan aktifitas dalam masing masing kelompok kerja.

Mengingat bahwa konsep bagi hasil mendorong perbaikan kualitas pelayanan maka hal itu sejalan dengan prinsip manajemen jasa, yaitu menerapkan filosofi “memuaskan konsumen” dan melakukan pendekatan secara menyeluruh untuk meningkatkan kualitas semua proses, produk, dan pelayanan yang berkesiambungan, mencapai hasil yang berkualitas total (TQM), serta menumbuh kembangkan kebanggaan karyawan atas prestasi kerjanya

Vincent Gaspersz dalam bukunya Manajemen Kualitas dalam Industi Jasa, mengemukakan bahwa pemberdayaan karyawan dapat dilakukan, antara lain dengan memperlakukan karyawan sebagaimana Anda ingin diperlakukan berkaitan dengan aspek Kejujuran (Honesty), Kesamaan (Equality), Kerja Sama (Team work), Pengakuan (Recognition), dan Kepercayaan (Trust) maka dengan sistem ini karyawan merasa terberdaya (empowered employees) karena mereka merasakan hal berikut.

a. Pekerjaan/usaha yang dijalankan merupakan milik mereka.

b. Mereka menjadi bertanggung jawab.

c. Mereka mengetahui di mana mereka berada/bekerja.

d. Memiliki pengendalian diri atas pekerjaan mereka.

Selanjutnya, Vincent mengemukakan penerapan konsep kualitas dalam produk jasa merupakan langkah pengorganisasian gerakan di tempat kerja (work place organization) dengan 
memberikan contoh apa yang telah dilakukan oleh perusahaan Jepang yang menerapkan konsep Kaizen di tempat kerja yang diberi nama "Gerakan $5 \mathrm{~S}$ " berikut.

1. Seiri (Bereskan)

Bedakan yang perlu dengan yang tidak perlu, singkirkan yang tidak perlu.

2. Seiton (Simpan dengan Teratur)

Barang harus disimpan dengan rapi sehingga siap pakai bila diperlukan.

3. Seiso (Bersihkan)

Pelihara tempat kerja agar selalu bersih.

4. Seiketsu (Kebersihan Pribadi)

Kebiasaan besih dimulai dari diri sendiri.

5. Shitsuke (Disiplin)

Taati prosedur kerja.

Konsep Kaizen merupakan suatu kesatuan pandangan yang komperhensif dan terintegrasi dengan maksud melakukan perbaikan secara terus menerus (continuous improvement). Dalam pelayanan jasa untuk suatu perbaikan, diperlukan komitmen yang tinggi dari aspek manusianya (motivasi), di samping aspek teknologi. Dengan penerapan manajemen kualitas di beberapa Rumah Makan "Padang" seperti Rumah Makan "Sederhana" misalnya, maka akan terasa kualitas pelayanannya cukup baik dan cepat

Karakteristik Jasa atau penyerahan jasa, seperti pelayanan rumah makan, dapat bersifat kuantitatif (dapat diukur) dan kualitatif (dapat dibandingkan). Beberapa karakter yang secara subjektif dievaluasi oleh pelanggan, antara lain sebagai berikut.

a. Fasilitas, jumlah personil, dan kuantitas peralatan.

b. Waktu tunggu, waktu proses.

c. Keandalan pelayanan.

d. Kebersihan, kenyamanan, dan estetika lingkungan.

e. Etika para karyawan.

Hal tersebut menyangkut perilaku dan performance individual yang secara langsung harus menjadi perhatian manajemen, seperti berikut ini.

1. Memilih personel berdasarkan kemampuan untuk memenuhi spesifikasi pekerjaan;

2. menciptakan lingkungan dan hubungan kerja yang aman dan nyaman;

3. menumbuhkan rasa pada semua personil agar mereka merasa memiliki keterlibatan yang mempengaruhi kualitas jasa yang diberikan;

4. mendorong peningkatan kualitas dengan pemberian pengakuan/penghargaan;

5. menetapkan tindakan terencana untuk memperbaharui atau meningkatkan keterampilan personil.

Pendidikan atau pelatihan personil tentang kualitas pelayanan harus tetap berjalan dalam kerangka penciptaan/peningkatan kepuasan konsumen. Menurut Phillip Kotler, kepuasan konsumen apakah senang atau kecewa, merupakan refleksi perbandingan antara kinerja suatu produk dan harapannya. Jika kinerja berada di atas harapan atau memenuhi harapan maka 
pelanggan/konsumen akan puas atau sebaliknya. Kepuasan pelanggan/konsumen memberikan dampak terciptanya loyalitas pelanggan, hubungan dengan pelanggan menjadi harmonis, dan pelanggan akan merekomendasikan (promosi) kepada calon pelanggan lain.

Penilaian konsumen adalah suatu ukuran mutlak bagi industri jasa. Reaksi pelanggan mungkin segera dengan cara berhenti menggunakan atau membeli jasa yang dimaksud tanpa pemberitahun kepada si pemberi jasa sehingga kehilangan peluang untuk melakukan tindakan korektif. Selanjutnya, Kotler mengidentifikasi beberapa metode untuk mengukur kepuasan pelanggan, antara lain melalui survei kepuasan dan keluhan/komplain pelanggan

Handi Irawan D. dalam bukunya 10 Prinsip Kepuasan Pelanggan mengemukakan bahwa keluhan yang disampaikan pelanggan merupakan ruang service recovery yang diberikan pelanggan sehingga upaya mempertahankan langganan dapat berjalan baik. Oleh karena itu, di banyak Rumah Makan "Padang" sering ditulis kata kata himbauan, seperi berikut ini. "Bila Anda Puas Sampaikan pada Sahabat Anda dan Bila Anda Kurang Puas Segera Sampaikan pada Kami”

Ada lagi satu hal yang unik dalam pembagian bagi hasil ala Rumah Makan "Padang" ini, yaitu pelaksanaan bagi hasil dilaksanakan setelah setiap 100 (seratus) hari. Perlu dicatat bahwa ketidakhadiran seorang pekerja akan mendapat potongan yang proporsional dan dipotong dari bagian yang akan diperolehnya. Mungkin tanpa disadari perhitungan bagi hasil setiap 100 hari sudah menciptakan formula bahwa setiap ketidakhadiran karyawan kan mendapat penalti 1/100 atau $1 \%$ untuk setiap hari kerja

Mengingat masa bagi hasil cukup lama, yaitu setiap 100 hari kerja maka kepada karyawan diberi kesempatan mengajukan bon pinjaman untuk memenuhi kebutuhan rumah tangganya dan akan diperhitungkan langsung pada saat pembagian hasil usaha.

\section{Sistem Kontrol}

Bila diamati lebih cermat, setiap piring lauk pauk yang beraneka ragam apakah daging, ikan, ayam, dan sebagainya selalu berisi 2 (dua) potong, kecuali sayuran. Setiap tamu/konsumen akan membayar apa yang telah dicicipi atau dimakan/diminum, dan bukan apa yang telah disajikan. Selain praktis, mudah, cepat, dan memenuhi aspek estetika, yaitu keharmonisan antara tempat/piring dengan isinya, maka standar penyajian tersebut sudah pasti memudahkan kontrol bagi pelayan dalam menghitung harga yang harus dibayar oleh konsumen dan terhindar dari salah duga mengenai jumlah porsi yang telah dinikmati/dimakan oleh konsumen. Perhitungan yang dibuat oleh unit pelayanan akan dihitung ulang oleh kasir guna menghindari kesalahan dalam penjumlahan angka sehingga tidak merugikan konsumen maupun pihak perusahaan

\section{PENUTUP}

\section{Simpulan}

Usaha bagi hasil sangat memotivasi karyawan untuk meningkatkan kinerjanya dan menumbuhkan rasa kepemilikan usaha dan tanggung jawab serta peningkatan kerja sama berkesinambungan antarsesama karyawan. Hal tersebut mewujudkan suatu tim yang padu dalam 
upaya peningkatan pelayanan kepada konsumen. Mengemukakan prinsip "Kepuasan Konsumen” merupakan paradigma baru merebut hati konsumen dalam rangka memenangkan persaingan

Bertambah banyaknya konsumen yang puas merupakan langkah promosi yang efektif dan cukup efisien karena promosi akan disampaikan dari mulut ke mulut. Pelanggan yang complain adalah pelanggan setia yang memberi ruang kesempatan pada pemberi jasa untuk melakukan service recovery sehingga loyalitas pelanggan dapat dipertahankan.

\section{DAFTAR PUSTAKA}

Gaspersz, Vincent. Manajemen Kualitas dalam Industri Jasa. Jakarta: Gramedia Pustaka Utama.

Golis, Christopher C. Empathy Selling. Jakarta: Gramedia Pustaka Utama.

Irawan D., Handi. 10 Prinsip Kepuasan Pelanggan. Jakarta: Media Elex Media Komputindo.

Kotler, Philip. Manajemen Pemasaran, Analisis, Perencanaan, Implementasi, dan Kontrol. Prenhallindo. 